\title{
China, the TPP and Intellectual Property
}

\author{
Peter Drahos
}

Published online: 1 February 2016

(C) Max Planck Institute for Innovation and Competition, Munich 2016

The Trans-Pacific Partnership (TPP) may yet turn out to be the agreement that most transforms national regulatory systems, perhaps even more so than the Uruguay Round (1986-1994) that delivered the World Trade Organization (WTO) and agreements such as the TRIPS Agreement. Much depends on how soon China joins the TPP.

There are two immediate objections to my opening paragraph. It assumes that the TPP will come into operation and that China is planning to join. A text of the TPP has been signed by twelve parties (Australia, Brunei, Canada, Chile, Japan, Malaysia, Mexico, Peru, New Zealand, Singapore, the United States and Vietnam), but each of these parties has to shepherd this text through its respective domestic treaty-making processes. The TPP does not need the approval of all its signatories to come into force. Six or more signatories making up at least $85 \%$ of the combined gross domestic product (GDP) of the original signatories would be enough to give the TPP legal force. The US with its 18 trillion dollar GDP does have to be part of the six.

In the US, politicians like Donald Trump will cast themselves as Horatius-like figures in the battle to save American jobs from the TPP. There will be drama and brinkmanship, just as there was with the WTO and the TRIPS Agreement. It tends to be forgotten that Intel in the final few days of the Uruguay Round led a successful charge against the entire package of agreements because it was not happy with the wording of the compulsory licensing provision in TRIPS (see the exception in Article 31(1)(c) for semiconductor chips). ${ }^{1}$ The US Biotechnology Industry Organization and the Pharmaceutical Research and Manufacturers of America,

\footnotetext{
${ }^{1}$ See P. Drahos and J. Braithwaite, Information Feudalism, New Press: New York, 148-149.

P. Drahos $(\bowtie)$

LLM; PhD

Regulatory Institutions Network, Australian National University and Centre for Commercial Law

Studies, Queen Mary, University of London, London, UK

e-mail: peter.drahos@anu.edu.au
} 
discontent with provisions in the TPP that allow members to choose between a minimum eight-year data exclusivity term for new biologics or a comparable outcome via a five-year term plus some other measures, will probably try similar tactics. My own view is that because the TPP represents a huge opportunity to influence the direction of national regulatory policy in the Asia Pacific, especially in the field of intellectual property, enough business lobbies will support it to prod Congress into voting in its favour. The US biotech and pharmaceutical industry also know that countries can be persuaded bilaterally to move to the desired (at least for the moment) 12-year term for biologics. One only has to look at the way in which the data protection standard in TRIPS, which does not specify a period of protection, receded into history as countries were persuaded to adopt data exclusivity periods.

The view that the US Congress will approve the TPP is plausible enough, but the claim that China is planning to join the TPP seems implausible. After all, it is one of the leaders in the Regional Comprehensive Economic Partnership (RCEP) negotiations, often depicted as the alternative to the TPP. A more likely scenario is that both the TPP and RCEP will emerge and these two agreements will over the decades becoming the stepping stones to a Free Trade Area of the Asia Pacific, such a free trade area having been proposed and discussed in the Asia Pacific Economic Forum since at least the 1990s.

However, it is also worth considering a scenario in which China does the unexpected and joins the TPP. One can think of many reasons for China not to join: China cannot accept the TPP's labour and environmental standards, its higher intellectual property standards or the entailed reforms of its state-owned enterprises. These objections all have weight, but perhaps not as much as might be first thought. China is no longer the lowest-cost location for labour and so comparatively modest provisions on labour standards are less of a problem. With the water in its major rivers not fit for human consumption and air pollution one of the biggest killers of Chinese people, tackling environmental problems has become a high priority for China. ${ }^{2}$ Tilting the metaphorical "balance" in intellectual property protection even further in favour of owners no longer holds fears for China. China's warm embrace of intellectual property systems continues to be revealed by the cold statistics: its patent office is the largest in the world in terms of applications and since 2010 it has accounted for more than half the annual increases in global trade mark filing activity. ${ }^{3}$ China will also have to reform its state-owned enterprises if it wishes to create a dynamic internal market to which investors will continue to look through the thick and thin of global growth. Obviously China would have to negotiate with the US to join the TPP, but it has already been through a WTO accession with the US. It knows what to expect.

There is perhaps another reason for China to think about the TPP. The Seventeenth National Congress of the Communist Party of China in 2007 committed China to the concept of "ecological civilization". China will need to acquire much greater regulatory capacity if it is to reach the basket of goals implicit

\footnotetext{
${ }^{2}$ See "Costs of Pollution in China: Economic Estimates of Physical Damages", World Bank, Washington DC, 2007.

3 See "World Intellectual Property Indicators 2014", WIPO.
} 
in ecological civilization. Scandals linked to poor regulation, such as the contamination of milk powder by the toxic compound melamine, which affected an estimated 300,000 infants, cause a massive loss of consumer confidence. ${ }^{4}$ Within China there will likely be a technocratic constituency that will see the TPP as a source of external pressure for improving its standards of domestic regulation in areas such as food and environmental regulation. The core logic here is that the TPP would be another source of pressure for China to adopt international regulatory standards of best practice, since these will generally be an improvement on China's current standards, as well as forming the best defence against investor-state actions.

Turning now to the TPP and intellectual property, many years ago John Braithwaite and I argued in a study of the globalization of business regulation that there were opportunities to ratchet standards up or down, with forum shifting being an important mechanism in the ratcheting process. ${ }^{5}$ In the case of intellectual property the ratchet mechanism has largely travelled in the direction of owner interests. In fact, I would argue that the spirit of "balance" was exorcised by owners from intellectual property policy long ago, although legions of apologists for the system will no doubt disagree with me. The TPP simply continues this long historical process.

The principal difference amongst the scenarios of a TPP with China included or a stepped TPP/RCEP convergence on a free trade area of the Asia Pacific is the speed at which the regulatory ratchet for intellectual property will operate. If China were to join the TPP, it would mean that the three largest economies in the world - the US, China and Japan - would have agreed to its intellectual property standards. The remaining members of coalitions such the BRICS (Brazil, Russia, India, China and South Africa) that have looked for more "balance" in the system as part of their development strategies would well and truly have had the wind taken out of their sails through China's departure. China might even see some longer-term advantages in some of these standards, such as the patent standards. China's dominance in the manufacture of active pharmaceutical ingredients (API - the substances used in the manufacture of a drug product) is well known. But, as in so many areas, the compliance of Chinese manufacturers with regulatory standards of best manufacturing practice is variable. Still, if China's price advantages in API manufacture were combined with improved regulatory compliance and more research and development around drug products, one could foresee the emergence of an industry with ambitions in pharmaceutical innovation.

The TPP has implications for the multilateral institutions of intellectual property, most notably the WTO and WIPO. Arguably they have been on a trajectory of declining relevance to multinational business interests for some time. One of the greatest forum shifts in the second part of the twentieth century was when US industry shifted intellectual property into the Uruguay Round negotiations, to the cost of WIPO's pre-eminence in the field. However, the WTO's ascendancy in intellectual property standard-setting proved to be just another click in the ratchet.

\footnotetext{
${ }^{4}$ See http://www.forbes.com/sites/yanzhonghuang/2014/07/16/the-2008-milk-scandal-revisited/.

5 J. Braithwaite and P. Drahos, Global Business Regulation, Cambridge University Press, Cambridge, 2000 .
} 
Even before the ink was dry on the TRIPS Agreement, states were negotiating intellectual property standards in free trade agreements that in some areas went beyond TRIPS standards.

The first TPP agreement, the one concluded amongst Brunei, Chile, New Zealand and Singapore in 2005 said very little in its seven articles about intellectual property, other than to affirm the standards to be found in the TRIPS Agreement. This first TPP is probably a genuine reflection of the interests of small to mediumsized countries that are net importers of intellectual property. The second TPP agreement is, to date, this century's most important forum shift for intellectual property owners, not just because of its present standards, but because the TPP opens the door to a free trade area of the Asia Pacific. This time, there are more than 80 articles and various annexes. Some provisions travel much more deeply into domestic sovereign space than the original corporate architects of TRIPS could ever have imagined. Article 18.37.2, for example, intrudes on claims drafting and is likely to bolster the invisible process of harmonization being led by the major patent offices that I have written about elsewhere. ${ }^{6}$ Predictably, the trade departments of the smaller countries in the negotiations, apparently forgetting about the first TPP, are putting a brave face on the intellectual property chapter outcomes, assuring their respective publics that their interests have been safeguarded. Time and text will tell.

\footnotetext{
${ }^{6}$ P. Drahos, The Global Governance of Knowledge: Patent Offices and their Clients, Cambridge
} University Press, Cambridge, 2010. 